MARKETING FINANCIAL SERVICES 


\title{
MARKETING FINANCIAL SERVICES
}

\author{
Arthur Meidan
}




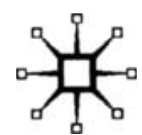

- Arthur Meidan 1996

Foreword @ Michael J. Baker 1996

All rights reserved. No reproduction, copy or transmission of this publication may be made without written permission.

No paragraph of this publication may be reproduced, copied or transmitted save with written permission or in accordance with the provisions of the Copyright, Designs and Patents Act 1988, or under the terms of any licence permitting limited copying issued by the Copyright Licensing Agency, 90 Tottenham Court Road, London W1T 4LP.

Any person who does any unauthorised act in relation to this publication may be liable to criminal prosecution and civil claims for damages.

The author has asserted his right to be identified as the author of this work in accordance with the Copyright, Designs and Patents Act 1988.

Published by

PALGRAVE MACMILLAN

Houndmills, Basingstoke, Hampshire RG21 6XS and

175 Fifth Avenue, New York, N. Y. 10010

Companies and representatives throughout the world

PALGRAVE MACMILLAN is the global academic imprint of the Palgrave Macmillan division of St. Martin's Press, LLC and of Palgrave Macmillan Ltd. Macmillan is a registered trademark in the United States, United Kingdom and other countries. Palgrave is a registered trademark in the European Union and other countries.

ISBN 978-0-333-55003-8

DOI 10.1007/978-1-349-24475-1

This book is printed on paper suitable for recycling and made from fully managed and sustained forest sources.

A catalogue record for this book is available from the British Library.

Transferred to digital printing 2002

Copy-edited and typeset by Povey-Edmondson

Tavistock and Rochdale, England 
To Rachel, with deep affection and love 


\section{Contents}

List of Tables $\quad \mathbf{x}$

List of Figures $\quad \mathrm{xii}$

List of Exhibits xiv

Foreword by Professor Michael J. Baker xvii

Preface $\quad \mathrm{xix}$

1 The Roles of Marketing in Financial Services 1 Introduction 1

The Main Characteristics of Financial Services 2

The Main Financial Services Sectors and their Functions 8

Recent Factors Affecting the Financial Services Market 14

The Elements of Marketing 18

2 Customer Behaviour and Market Segmentation 23

Consumer Behaviour and Attitudes 23

Types of Market Segmentation 33

Segmentation in Insurance 42

Segmentation of Retail versus Corporate Markets $\quad 45$

3 Marketing Research 50

The Roles and Functions of Marketing Research in Financial Services 50

The Research Methodology 53

Evaluating Marketing Research Programmes 58

Applications of Marketing Research in Financial Services 61

4 Product Development 83

The Financial Product 84

Special Features of Product Development $\quad 89$

The Financial Product Life Cycle 97

Product Development Strategies 105

The Implications of New Technology for Financial Product

Development 110

5 Marketing of Credit Cards 118

Introduction 118 
The Main Types of Credit Card

The Development of Bank Credit Cards in the USA, Japan and Western Europe 124

Advantages and Limitations of the Credit Card System 128

Credit Cardholders' Profiles 131

Credit Card Market Segmentation 134

Marketing Strategies for Credit Cards 137

Conclusions: The Future of Credit Cards 139

6 Pricing 142

Pricing Systems in Banking 142

Pricing Methods 148

Building Society Pricing 151

Insurance Pricing 155

Pricing Policies: Strategic versus Tactical Goals 162

7 Advertising and Communications

165

The Roles of Advertising 167

Advertising Channels 175

Promotions 181

Personal Selling 183

Publicity 186

The Contribution of Advertising and Communications to the

Financial Services Marketing Programme 190

8 Salesforce Management 193

The Roles of Financial Advisers in Financial Services

Organisations 194

Characteristics and Requirements for High Selling

Performance 202

Service Quality and Customer Care 208

9 Branch Location and Distribution 212

Means of Distributing Financial Services $\quad 212$

Branch Location Decisions 224

Channels of Distribution in Insurance 231

10 Branch Administration 241

Creating the Branch Image 241

Branch Design and Layout 245

The Process of Branch Administration $\quad 250$

The Functions and Roles of Branch Managers 257

11 Marketing Planning, Administration and Control 265

Corporate Planning 265 
Organisation of Marketing Operations 273

Administering the Marketing Programme 277

Marketing Controls 285

Performance Appraisal 291

12 Marketing Strategies for Financial Services 295 Introduction 295

Formulating a Marketing Strategy 295

Types of Marketing Strategy for Financial Services 300

Selecting a Marketing Strategy $\quad 308$

Index $\quad 315$ 


\section{List of Tables}

1.1 UK banking: personal and business customers, number of branches and total assets 8

2.1 Stages in financial services customers' decision process

2.2 Some major bases for market segmentation in retail financial services $\quad 35$

2.3 Insurance customer brand/policy preferences 45

3.1 The advantages of some major survey instruments - a comparison 55

3.2 The disadvantages of the major survey instruments - a comparison 55

3.3 Women's banking behaviour - a profile of clusters $\quad 67$

3.4 Demand and supply indices for banks in the UK 69

3.5 How branch managers see their functions 72

4.1 Planning financial services development 91

5.1 Bank and T\&E credit card comparison 123

5.2 Comparison of bank credit card usage in the USA versus Western Europe 125

5.3 Advantages and limitations of bank credit cards - to the cardholder, retailer and the card company/bank group 129

7.1 Advertising expenditure by banks and building societies 166

7.2 Characteristics of the various promotional channels for financial services 176

8.1 Determinants of success for financial advisers in insurance some major approaches 198

8.2 Optimising sales time allocation by considering both customer type and product group(s) 199

9.1 Electronic fund transfer systems - some advantages and limitations 223

9.2 The decision-making process for setting up a new bank or building society branch 227

9.3 The major quantative methods for optimising financial services branch locations 232

10.1 Mean scores of importance and usage of various merchandising techniques in bank branches 249

10.2 Job responsibilities of bank branch managers - importance, time spent and job satisfaction 259

10.3 Major branch features and staff characteristics required by building society branch management 262 
11.1 Appraising marketing performance in financial service organisations 294

12.1 Stages in formulating a financial services strategy 297 


\section{List of Figures}

1.1 The financial institution management system 6

1.2 The hazards generating the need for insurance marketing 10

1.3 The insurance marketing mix

12

1.4 The marketing approach to financial services 19

1.5 Financial institutions' dual marketing task 19

1.6 The financial institution marketing management system 21

2.1 The main factors influencing financial services 24

2.2 The consumer process 30

2.3 Save-spend behaviour and social class $\quad 37$

3.1 The roles of marketing research in financial services 52

3.2 Main stages of a financial service market survey/research 54

3.3 The four main types of market survey instrument 57

3.4 The process and techniques of market segmentation 62

3.5 Demand and supply indices for banks in the UK 69

3.6 Performance analysis of major credit card issuers $\quad 76$

3.7 Ideal bank segments for small business executives' bank position and attributes 78

4.1 A taxonomy of financial products/services on offer 92

4.2 The main types of insurance products 93

4.3 Alternative sources of new financial product/service ideas 96

4.4 The main stages in launching new financial products

4.5 The financial product life cycle 102

4.6 Conventional life assurance products 104

5.1 Factors affecting the use of credit cards 132

6.1 Internal and external factors affecting mortgage pricing in the building society industry 153

6.2 Factors affecting price calculation (rate making) in insurance 156

6.3 The major methods of insurance pricing 158

7.1 Advertising and communication mix in financial services 171

8.1 Identifying prospects in bank branches 205

8.2 The five main stages in selling financial services 207

9.1 Barriers to provision of delivery systems in financial services 213

9.2 Distribution channels for banks and building societies 214

9.3 Not all branches are the same 219 
9.4 Direct versus indirect distribution channels in insurance 235

10.1 Traditional branch layout 246

10.2 Open-plan layout 246

10.3 A systematic analysis of financial services branch performance 256

10.4 The roles and functions of branch managers 257

11.1 Marketing plan formulation - main stages 266

11.2 Bank $\mathrm{ABC}$ corporate planning cycle 268

11.3 Some of the details and information presented in a marketing plan 272

11.4 Typical banking organisation: staff functions and main divisional lines 274

11.5 Typical building society organisation and marketing functions 276

11.6 Typical insurance marketing department organisation 278

11.7 Important aspects of marketing cash-management services 283

11.8 The relationships between banks offering international services and multinational corporations customers 286

11.9 Types of bank marketing control 287

12.1 The role of marketing strategy in financial services 296

12.2 Alternative offensive strategies 301

12.3 Defensive and rationalisation marketing strategies 305

12.4 Financial services organisation marketing strategy plan 310 


\section{List of Exhibits}

1.1 Competition in the financial services market 2

1.2 Some recent technological developments in financial services marketing 4

1.3 Environmental factors and competition in the insurance market 9

1.4 Building societies' fight for market share 13

1.5 Customer behaviour and segmentation 14

1.6 The impact and effects of deregulation 15

1.7 Quality, client relationships and ethical issues 17 .

2.1 The importance of culture for bank marketing in Islamic countries 25

2.2 Cultural influences in life insurance marketing to senior citizens in Hong Kong 26

2.3 Segmenting the rich 27

2.4 The use of demographic variables for segmentation 36

2.5 Psychographic and behavioural segmentation in the insurance sector 38

2.6 Segmentation in the student market - some recent deals and incentives offered to students 41

2.7 Banks reassess customer service 43

2.8 The role of perceived risk and financial services consumer behaviour 43

3.1 HICLUS (hierarchical clustering) - application to banking 64

3.2 Mergers and acquisitions in financial services - how marketing research could help 77

3.3 Bank marketing strategies for the small business sector $\quad 79$

4.1 Midland Bank's FirstDirect 95

4.2 ATMs - applications and strategies 100

4.3 New technology in financial services - from Eftpos to expert systems 113

4.4 Problems behind the new technology and their possible solutions 115

5.1 A history of credit cards 119

5.2 The problem of card fraud - how it affects credit card profitability 122

5.3 Should card issuers target the big spenders? 138 
5.4 Marketing strategy for credit cards - how a Japanese credit card company aims to become global 140

6.1 The international money order pricing policy at Barclays 143

6.2 Relationship pricing - towards a new pricing approach?

6.3 How much do the various banking services cost?

6.4 Pricing mortgages by family status 152

6.5 The functions of reserves in insurance pricing

6.6 Pricing and risk classification 160

6.7 Pricing policy for non-interest-earning products at Broomhill Bank 162

7.1 The roles of advertising in launching Trustcard at TSB

7.2 Finance advertisements fail to relate to women 169

7.3 The advertising of FirstDirect 172

7.4 Which are the most recalled advertisements? 175

7.5 Prospecting: how to obtain customers in insurance 185

7.6 Financial services public relations companies are growing in scope 187

7.7 Financial services advertising targets sponsorship 189

7.8 Using communication mix to promote savings in the child market segment 190

8.1 The importance of agents' professionalism in selling insurance 194

8.2 'Salesperson wheel' - an approach to managing insurance salespersons' time 201

8.3 Bank branches' main selling functions 204

8.4 Methods of evaluating insurance financial advisers' performance 206

9.1 The distribution network of the European giro group 215

9.2 The rationalisation of bank branches 216

9.3 How electronic delivery could affect financial services distribution 221

9.4 Qualitative approaches to bank branch location 230

10.1 The building society branch image 242

10.2 Branch image and profitability 244

10.3 Is there a universal style of financial services branch? 247

10.4 Control mechanisms for improving branch performance 256

10.5 How Canadian bank branch managers face the new market trends 261

11.1 Mergers in the building society sector as part of planning activity 269

11.2 Branch administration for the international market 281

11.3 How the single European market is likely to affect financial services administration and control 285 
11.4 The implications of management information systems in controlling marketing programmes 289

11.5 Controlling service quality in financial institutions 291

12.1 How insurance companies decide on possible marketing strategies 299

12.2 Are mergers and acquisitions in financial services geographical expansions or rationalisation strategies? 302

12.3 Market penetration strategy at the Bradford and Bingley Building Society 303

12.4 Strategic alliances in the financial services market 303

12.5 Rationalisation strategies in building societies 308

12.6 Some marketing strategies in the building society sector 310 


\section{Foreword}

Marketing Financial Services is the worthy successor to Arthur Meidan's Bank Marketing Management, which appeared in the Macmillan series Studies in Marketing Management in 1984. Since then major changes have occurred in the nature, structure and operations of the financial services sector that have had a significant impact upon both retail and commercial banking at home and abroad. It is against this background that one must greatly welcome the appearance of Marketing Financial Services, which incorporates much of Bank Marketing Management in an extensively revised and updated format, together with much new material with insurance, building societies, credit card and so on.

In the foreword to Bank Marketing Management I expressed the view that even the casual observer of the banking scene could not have helped becoming aware of the immense changes that had occurred and continued to take place. My opinion then, and now, was that money is the classical undifferentiated product and the only way in which those dealing in the commodity can secure any competitive advantage is through the range and quality of the services they offer. To determine what these service needs are they must undertake market research; to cater for these needs they require a product development function; to promote the existence of their new products they need advertising; and to sell them they need good packaging, competitive prices and sales incentives. I concluded that 'in sum, then, banks need a marketing approach to their business, and this book has been written especially to show how to develop and apply such an orientation'.

More than a decade later these views are seen to be just as valid as they were in the early 1980s. 1983 saw the first publication of the International Journal of Bank Marketing. In 1993 it published a special issue (volume 11, number 6) on the theme of 'Ten Years of Bank Marketing: Retrospect and Prospect'. The guest editors, Mike Wright and Chris Ennew, were kind enough to invite me to contribute to this theme and this I was pleased to do. As a generalist I would be the first to admit that I have not been closely involved with the detail of marketing financial services. That said, as a customer and interested observer I have come to the reluctant conclusion that there is a clear lack of marketing in both principle and practice in the UK banking system - a criticism that applies to a considerable degree to the broader field of financial services. In my article entitled 'Bank Marketing - Myth or Reality?' I came to the conclusion that the application of marketing to financial services is largely one of trappings rather than substance. 
Among these trappings of marketing, first identified by Charles Ames in a Harvard Business Review article in 1970, may be numbered declarations of support from top management, the creation of marketing organisations containing numerous people with 'marketing' in their title, and increased marketing expenditure on advertising and publicity. While all these activities may contribute to improved performance, Ames went on to argue that they are 'no guarantee of marketing success. The kind of change that is needed is a fundamental shift in thinking and attitude throughout the company so that everyone in every function area places paramount importance on being responsive to market needs'.

To understand fully the true substance of marketing, this book offers an important point of departure. Arthur Meidan is eminently well qualified to write what I am sure will be seen as a valuable contribution to the growing literature on the marketing of financial services. As well as extensive knowledge of current thinking on the subject, Professor Meidan possesses two other distinct advantages. First, he has actively participated in management development programmes for people in the financial services sector, and so is more familiar with the philosophical problems of persuading professional people that 'marketing' is not an anodyne designed to disguise what was discarded as high pressure selling. By the same token he knows from personal experience just what topics are of interest to financial services managers and how to present these clearly and succinctly. Second, in preparing this much extended version of his earlier work, Arthur Meidan has had the benefit of direct comments and criticism from senior practitioners and, being a marketing man, he has incorporated this consumer feedback into his product design. In addition to an authoritative discussion and exposition of the subject matter this book also contains a number of 'exhibits', which consist of short case studies, illustrations, examples and descriptions of situations from various financial services sectors in the UK and abroad that both emphasise and elaborate on the issues under discussion.

For those seeking to put substance into their marketing effort, read on!

University of Strathclyde

Michael J. BAKeR

Glasgow 


\section{Preface}

The original inspiration for this book came from two sources. Firstly, in the last few years there has been clear evidence of a need for a basic text in marketing financial services that could be used by students in various courses offered by universities and other tertiary institutions of education as well as by practitioners, and which incorporates and discusses in some depth the problems and issues relevant to the various financial services sectors: banking, insurance, building societies and credit cards.

Secondly, I have had substantial experience of teaching insurance and, separately, bank marketing courses to practitioners in these sectors of the financial services through post-experience courses and seminars in Western Europe, the Middle East and North and South America. This experience identified a gap in the literature: there are indeed very few books that present marketing problems peculiar to sectors such as insurance or building societies within one book cover, generalising when there is common ground amongst the various financial services sectors, yet discussing separately the special features, applicability, theories and practices that are relevant to one particular financial services category only.

This book recognises that the major function of the financial services marketer is decision making. It focuses, therefore, on the major types of decisions - and problems - facing financial services marketing executives in the present unstable and competitive environment, which is affecting this industry at both national and international level.

The text presents a large number of examples and applications, usually in the form of 'exhibits', which are short case studies, descriptions of situations, examples or the results of research and studies in both the UK and overseas.

Many people have been influenced in the successful completion of this book. It is with gratitude that these individuals are acknowledged here.

Acknowledgements are extended to Mr G. Burn for permission to reproduce some of the material from my book Insurance Marketing. To Professor Michael J. Baker, many thanks for writing the Foreword and for his general support of this initiative. I am indebted to Mr Kevin Gavaghan (former Director of Marketing and Communication at Midland Bank), Dr Barbara Lewis (former Editor of The International Journal of Bank Marketing), and Professor Adrian Payne of Cranfield Business School for writing supporting statements and comments on the book. I am also grateful to my colleague, Dr R. S. Minhas, for his comments in reviewing the manuscript.

Acknowledgements are also extended to a number of former and present students of mine at Sheffield University, and in particular to I. Lim, C. Kuen, N. 
Wong and C.K.H. Chan for their permission to use and reproduce some of their research findings and study material.

Finally, I am indebted to Mrs K. Hewitt, Ms N. Keally and my secretary Ms M. Gleadall, who have all assisted with the typing of the manuscript.

Responsibility for any errors or omissions is mine. 